\title{
THE ROLE OF CENTRAL NECK DISSECTION IN DIFFERENTIATED THYROID CANCER
}

\author{
By \\ Mohamed I. El-Anany, Mohamed M. Ahmed*, Ahmed A. Abdel Rahim \\ Departments of General Surgery and Surgical Oncology*, Faculty of Medicine, Al-Azhar \\ University (Cairo) \\ Corresponding author: Ahmed A. Abdel Rahim, Mobile: 01025098438 \\ Email: ahmedfouda86@gmail.com
}

\begin{abstract}
Background: Thyroid cancer is the most common endocrine malignancy and differentiated thyroid cancer has a 10-year survival rate of $\square 90 \%$. Cervical lymph node metastases are a common feature of papillary thyroid cancer while follicular thyroid cancer often spreads hematogenously.

Objective: To evaluate the role of central neck dissection in the management of differentiated thyroid cancer as regard its impact on both morbidity and overall outcome.

Patients and Methods: This was a prospective cross sectional study conducted on 30 patients diagnosed as differentiated thyroid cancer (DTC) and admitted at the Surgical Oncology Department of Al-Azhar University Hospitals and Damanhour Oncology Centre. All patients of the study subjected to clinical assessment by complete history taking, complete laboratory investigations, imaging studies and tissue diagnosis by fine needle aspiration cytology.

Results: the relation between positive LNs and tumor of $2-4 \mathrm{~cm}$ size which was central group which commonly diagnosed clinically and the absence commonly diagnosed radio logically and also associated with capsular invasion of thyroid. The most common type of the tumor was papillary type with a little percentage of follicular type and I131 was used as appellatives therapy for some of these cases.
\end{abstract}

Conclusion: central neck dissection is still beneficial especially in high risk group of cases where there was capsular invasion.

Key words: central neck dissection, differentiated thyroid cancer.

\section{INTRODUCTION}

Thyroid cancer is the most common endocrine malignancy, and its incidence is increasing at the highest rate among cancers in both the US and worldwide (Pellegriti et al., 2013). Differentiated thyroid cancer (DTC) has a 10-year survival rate of greater than $90 \%$. However, despite its promising survival rate, local recurrence occurs in $20-30 \%$ of papillary thyroid cancer patients due to clinically undetectable metastasis to cervical lymph nodes (Friedman et al., 2011). Cervical lymph node metastases are a common feature of papillary thyroid cancer (PTC), with an incidence between 20-90\% (Haugen et al., 2016). Conversely, follicular thyroid cancer (FTC) often spreads hematogenously, and rarely metastasizes to the cervical lymph nodes. Hurthle cell thyroid cancer (HTC) is a rare and aggressive form of differentiated thyroid cancer of follicular cell origin; HTC displays a lower rate of 
cervical lymph node metastasis compared to PTC (Goffredo et al., 2013).

The prognostic value of nodal metastases is controversial: some Authors consider their presence predictive of local disease recurrence, but overall diseasespecific survival does not seem to be adversely affected. Loco-regional metastasis to the cervical lymph node network can take place in one or more of the levels originally described by Robbins. Cervical lymph node levels VI and the upper part of VII, most commonly known as the central compartment, are often involved in thyroid malignancy. This anatomical district is considered to be the first echelon of nodal metastases in all thyroid carcinomas (Giugliano et al., 2014).

The central compartment is bounded by the hyoid bone (superior), carotid artery (lateral), and sternal notch or innominate artery (inferior). The American Thyroid Association (ATA) defines central compartment neck dissection as "comprehensive, compartment-oriented removal of the prelaryngeal and pretracheal nodes and at least one paratracheal lymph node basin." The regional metastases to the cervical lymph nodes were traditionally believed to have an effect only on recurrence rate, but not mortality (Hennessy and Goldenberg, 2016).

Some authors recommend routine central neck dissection (CND) in order to prevent a future recurrence, citing the high risk of positive lymph nodes, better outcomes, and a lower morbidity rate associated with this initial operation, whereas others maintain that this procedure increases the risk of injury to the parathyroid glands and recurrent laryngeal nerves, without any demonstrable benefits in terms of longterm survival (Barczyński et al., 2013). Central neck dissection allows for accurate pathologic staging of the lymph nodes and treatment of the micrometastases that may be responsible for the recurrence or persistence of the disease (Giordano et al., 2012). In addition, recurrence in this compartment is difficult to treat surgically and may become complicated, while central lymph node dissection during the initial thyroid surgery can be performed without extending the wound (Pietro et al., 2013).

The most important morbidities associated with CND consist of recurrent laryngeal nerve damage and hypocalcemia related to parathyroid hypo-function or to accidental parathyroidectomy. The incidence of surgical complications is variable, surgeon and centre-dependent, and correlates with pathological features of the tumor. It is important to keep in mind the data available in the most current scientific literature: transient hypocalcaemia has been reported with an incidence of up to $30 \%$, while recurrent laryngeal nerve injury has been observed with an incidence of in 1-3\%. Complications are an unpleasant, and sometimes unavoidable, which are a reality of intense surgical activity. Minimization of their incidence can only come from accurate knowledge of the relevant surgical anatomy, standardized and careful surgical techniques and clear therapeutic indications (Giugliano et al., 2014).

The use of routine prophylactic central neck dissection for the treatment of 
differentiated thyroid cancer has been an area of debate over the past few decades. The decision of when to perform a prophylactic central neck dissection must be based on retrospective studies and expert opinion. The American Thyroid Association recommended that prophylactic central neck dissection should be reserved only for the use in invasive or advanced (T3 and T4) papillary thyroid cancers. When planning the initial treatment of a patient with differentiated thyroid cancer one must determine the efficacy of central neck dissection. In conclusion, the benefits of prophylactic central neck dissection are too meager to outweigh its associated risks, and thus the use of central neck dissection should be reserved for high-risk patients in the hands of an experienced surgeon (Hennessy et al., 2016).

\section{AIM OF THE WORK}

The aim of the present work is to evaluate the role of central neck dissection in the management of differentiated thyroid cancer as regard its impact on both morbidity and overall outcome.

\section{PATIENTS AND METHODS}

This was a prospective cross-sectional study conducted on 30 patients diagnosed as differentiated thyroid cancer (DTC) and admitted at the Surgical Oncology Department of Al-Azhar University Hospitals and Damanhour Oncology Centre.

This prospective study included the patients with the following criteria: presence of clinically positive or radio logically suggestive LN enlargement in any patients undergoing thyroidectomy, all cases diagnosed as DTC by biopsy at the preoperative workup and planned to be operated and cases with high suspension of malignancy as: rapid increase of size in short time, local signs of infiltration to the surrounding structures like change of voice, dysphagia, ear pain, blackout,...etc. The study was submitted for approval of the Hospital Ethics Committee.

All patients in the present study were subjected to the following:

Preoperative assessment: A. Clinical evaluation: complete history-taking, thorough clinical examination, laboratory investigations: preoperative laboratory work up of the patients will include the following: Complete blood picture, blood glucose level. - Renal function tests. - Liver function tests. - Thyroid profile (T3, T4, TSH) and thyroid antibodies, serum calcium level. C. Imaging: ultrasound neck, CT neck in selective cases, fiberoptic laryngoscopy; Pathology: Fine needle aspiration cytology (FNAC) with or without US guidance from any suspicious nodule.

Operative procedure: Under general anesthesia with intubation while the patient in the supine position with neck extension thyroidectomy then central neck dissection will be performed. Routine identification of recurrent laryngeal nerve and the parathyroid gland will be identified and preserved. Hemostasis will be ensured throughout the surgery. Suction drain will be inserted.

We follow the surgical technique discussed by Prescott and Udelsman (2012), for detailed steps of central neck dissection.

Postoperative assessment including Clinical assessment: voice changes, 
manifestations of hypocalcemia, and amount of drainage. Laboratory assessment of serum calcium level, Full histopathological examination of both thyroid gland and central compartment obtained lymph node specimens.

\section{Statistical analysis:}

The collected data were tabulated and analyzed using SPSS version 16 software
(SPSS Inc, Chicago, ILL Company). Categorical data were presented as number and percentages while quantitative data were expressed as mean \pm standard deviation (S.D) and range. Chi square test (X2), or Fisher's exact test (FET) were used to analyze categorical variables.

\section{RESULTS}

\section{Demographic Data:}

The age of patients ranged between 1866 years with a mean age of $44.5 \square 18.7$ years. Seven of the patients were males
$(7 / 30,23.33 \%)$ while 23 were females $(23 / 30,76.66 \%)$ with a male to female ratio of 1:3.3 (Table 1).

Table (1): Demographic data of the studied patients

\begin{tabular}{|ll|c|c|c|}
\hline \multicolumn{2}{|c|}{ Parameters } & \multicolumn{1}{c|}{ No. } & $\%$ & Patients \\
\hline Sex: & Male & 7 & $23.33 \%$ & \\
& Female & 23 & $76.66 \%$ & 0.01 \\
\hline Age: & & \multicolumn{2}{|c|}{$18-66$} & \\
& Range & \multicolumn{2}{|c|}{$44.5 \pm 18.7$} & \\
& Mean \pm S.D & \multicolumn{2}{|c|}{. } & \\
\hline
\end{tabular}

During physical examination 27 cases $(90 \%)$ were firm in consistency while three cases $(10 \%)$ had hard consistency and the statistical analysis revealed that firm consistency is the most common in our cases $(\mathrm{P}=0.001)$ (Table 3$)$. A retrosternal extension of the swelling present in two cases $(2 / 30,6.7 \%)$ while the common presenting symptom was an evident neck swelling present in 28 cases (93.3\%) $(\mathrm{P}=0.01)$ (Table 2).

Table (2): Clinical examination of patients of the study

\begin{tabular}{|l|c|c|c|}
\hline \multicolumn{1}{|c|}{ Clinical finding } & No. & $\mathbf{\%}$ & P \\
\hline Consistency: & & & \\
Firm & $\mathbf{2 7}$ & $\mathbf{9 0 \%}$ & $<\mathbf{0 . 0 0 1}$ \\
Hard & $\mathbf{3}$ & $\mathbf{1 0 \%}$ & \\
\hline Retrosternal extension: & & & \\
No & $\mathbf{2 8}$ & $\mathbf{9 3 . 3 \%}$ & $<\mathbf{0 . 0 0 1}$ \\
Yes & $\mathbf{2}$ & $\mathbf{6 . 7 \%}$ & \\
\hline
\end{tabular}


By ultrsonographic and CT examination of the neck; 17 cases $(17 / 30$, $56.7 \%$ ) had single nodule, 8 cases $(26.7 \%)$ had unilateral multiple nodules while 5 cases had bilateral multiple nodules. The statistical analysis revealed that the single nodule was the most common finding in cases of our study $(\mathrm{P}=0.021)$. Twentyseven $(90 \%)$ cases had microcalcifications while only 3 cases $(10 \%)$ had no calcification. The diameter of the nodules ranged between $5-28 \mathrm{~mm}$ with a mean diameter of $14.3 \pm 6.7 \mathrm{~mm}$ (Table 3).

Table (3): Imaging of the swelling in patients of the study

\begin{tabular}{|l|c|c|c|}
\hline \multicolumn{1}{|c|}{ Variable } & No. & \% & P \\
\hline Number of nodules: & & & \\
Unilateral multifocal & 8 & $26.7 \%$ & $\mathbf{0 . 0 2 1}$ \\
Bilateral multifocal & 5 & $16.7 \%$ & \\
Single nodule & 17 & $56.7 \%$ & \\
\hline Microcalcification: & 27 & $90 \%$ & $\mathbf{0 . 0 0 1}$ \\
Yes & 3 & $10 \%$ & \\
No & \multicolumn{2}{|c|}{$5-28$} & \\
\hline Diameter & \multicolumn{2}{|c|}{$14.3 \pm 6.7$} & \\
Range & \multicolumn{2}{|}{} \\
Mean \pm S.D & \multicolumn{2}{|c|}{} \\
\hline
\end{tabular}

Ten cases $(33.3 \%)$ had tumor size belonged to $\mathrm{T} 1,6(20 \%)$ cases belonged to $\mathrm{T} 3$, and no case $(0.0 \%)$ belonged to $\mathrm{T} 4$ while 14 cases $(46.7 \%)$ belonged to $\mathrm{T} 2$ which was the statistically significant type in our cases. In addition 18 cases $(60 \%)$ had no LN metastasis and 12 cases (40\%) belonged to $\mathrm{N} 1$ stage of lymph nodes.Also, all cases had no distant metastasis (100\%) (Table 4).

Table (4): TNM staging of the swelling in patients of the study

\begin{tabular}{|c|c|c|c|}
\hline Variable & No. & $\%$ & $\mathbf{P}$ \\
\hline $\begin{array}{ll}\text { Tumor size: } & \mathbf{T}_{\mathbf{1}} \\
\mathrm{T}_{2} & \\
\mathrm{~T}_{3} \\
\mathrm{~T}_{4}\end{array}$ & $\begin{array}{c}10 \\
14 \\
6 \\
0\end{array}$ & $\begin{array}{c}33.3 \% \\
46.7 \% \\
20 \% \\
0.0 \% \\
\end{array}$ & $<0.01$ \\
\hline $\begin{array}{ll}\text { L.N status: } & \mathbf{N}_{\mathbf{0}} \\
\mathrm{N}_{1} & \\
\end{array}$ & $\begin{array}{l}18 \\
12 \\
\end{array}$ & $\begin{array}{l}60 \% \\
40 \%\end{array}$ & $>0.05$ \\
\hline $\begin{array}{ll}\text { Distant metastasis: } & \mathbf{M}_{\mathbf{0}} \\
\mathrm{M}_{1} & \\
\end{array}$ & $\begin{array}{c}30 \\
0\end{array}$ & $\begin{array}{l}100 \% \\
0.0 \% \\
\end{array}$ & 0.001 \\
\hline
\end{tabular}

Post-operatively, vocal cord immobility was present in 2 cases $(6.7 \%)$, temporary hypocalcemia in 4 cases $(13.3 \%)$, and hematoma was present in another two cases $(6.7 \%)$. Of our patients

only one needed to be admitted to ICU $(3.3 \%)$ and the total hospital stay ranged between 1-4 days with a mean of $1.3 \pm 0.65$ day (Table 5). 
Table (5): Postoperative complications in patients of the study.

\begin{tabular}{|c|c|c|c|}
\hline Variable & No. & $\%$ & $\mathbf{P}$ \\
\hline $\begin{array}{l}\text { Vocal cord mobility: } \\
\text { Mobile } \\
\text { Immobile }\end{array}$ & $\begin{array}{c}28 \\
2 \\
\end{array}$ & $\begin{array}{c}93.3 \% \\
6.7 \% \\
\end{array}$ & 0.001 \\
\hline $\begin{array}{l}\text { Temporary hypocalcemia: } \\
\text { Yes } \\
\text { No }\end{array}$ & $\begin{array}{c}4 \\
26\end{array}$ & $\begin{array}{l}13.3 \% \\
86.7 \%\end{array}$ & 0.001 \\
\hline $\begin{array}{l}\text { Presence of hematoma: } \\
\text { Yes } \\
\text { No }\end{array}$ & $\begin{array}{c}2 \\
28\end{array}$ & $\begin{array}{c}6.7 \% \\
93.3 \%\end{array}$ & 0.001 \\
\hline $\begin{array}{l}\text { I.C.U admission: } \\
\text { Yes } \\
\text { No }\end{array}$ & $\begin{array}{c}1 \\
29 \\
\end{array}$ & $\begin{array}{c}3.3 \% \\
96.7 \% \\
\end{array}$ & 0.001 \\
\hline $\begin{array}{l}\text { Total hospital stay (day): } \\
\text { Range } \\
\text { Mean } \pm \text { S.D }\end{array}$ & \multicolumn{2}{|c|}{$\begin{array}{c}1-4 \\
1.3 \pm 0.65\end{array}$} & \\
\hline
\end{tabular}

By microscopic examination of the dissected central LNs, +ve LN were found in 18 cases $(60 \%)$ with combined contralateral in 8 cases $(26.6 \%)$, and the number was ranging from $4-12$ in ipsilateral and from 1-3 in contralateral LNs. In the lateral LNs, +ve LNs were found in 7 cases $(23.3 \%)$, and the number was ranging from 3-7 (Table 6).

Table (6): Microscopic examination of the removed L.N in patients of the study

\begin{tabular}{|l|c|c|}
\hline \multicolumn{1}{|c|}{ Variable } & No. & $\%$ \\
\hline Central L.N: & & \\
No. of dissected L.Ns & $8-21$ & \\
+ve L.N (cases) & 18 & $60 \%$ \\
+ve L.Ns (No.) & $4-12$ & \\
+ve ipsilateral L.Ns & 18 & $60 \%$ \\
Combined ipsilateral + contralateral L.N & 8 & $26.6 \%$ \\
+ve contralateral L.N & $1-3$ & \\
\hline Lateral L.N: & $17-30$ & \\
No. of dissected L.Ns & 7 & \\
+ve L.Ns (cases) & $3-7$ & $23.3 \%$ \\
+ve L.Ns (No.) & \\
\hline
\end{tabular}

According to the presence or absence of LNs in relation to the size of the tumor; the most common tumor size that didn't have LNs was the T1 group $(6 / 10,60 \%)$ $(\mathrm{P}=0.031)$ while the most common tumor size that have LNs was T2 $(10 / 20,50 \%)$ $(\mathrm{P}=0.021)$ (Table 6).

In T1 group of cases LNs most commonly present in the central group
$(4 / 4,100 \%)(\mathrm{P}=0.021)$; in addition in $\mathrm{T} 2$ group of cases LNs most commonly present in the central group $(6 / 10,60 \%)(\mathrm{P}$ $=0.023$ ) while in $\mathrm{T} 3$ group of cases also LNs most commonly present in central group $(3 / 6,50 \%)(\mathrm{P}=0.000)$ (Table 6).

Positive central and positive lateral LNs was more commoly in T3 group without significant relation to the tumor size $(\mathrm{P}=$ 
0.235). while positive central with negative lateral LNs was significantly present in group of $\mathrm{T} 1$ tumor size $(\mathrm{P}=$ 0.034 ) and finally negative central lymph nodes with positive lateral nodes was commonly present in $\mathrm{T} 3$ group of cases without any significant relation to the tumor size $(\mathrm{P}=0.326)$ (Table 7).

Table (7): Relation between the size of tumor and positive L.Ns (central and lateral)

\begin{tabular}{|l|c|c|c|c|}
\hline \multicolumn{1}{|c|}{ Variable } & $\begin{array}{c}\text { T1 } \\
(\mathbf{n = 1 0})\end{array}$ & $\begin{array}{c}\text { T2 } \\
(\mathbf{n = 1 4})\end{array}$ & $\begin{array}{c}\text { T3 } \\
(\mathbf{n = 6})\end{array}$ & $\mathbf{P}$ \\
\hline No. L.Ns & $\mathbf{6 ( 6 0 \% )}$ & $\mathbf{4 ( 4 0 \% )}$ & $\mathbf{0 ( 0 . 0 \% )}$ & $>\mathbf{0 . 0 5}$ \\
\hline Presence of L.Ns: & $\mathbf{4 ( 2 0 \% )}$ & $\mathbf{1 0}(\mathbf{5 0 \%})$ & $\mathbf{6 ( 3 0 \% )}$ & \\
+ve central + +ve lat & $0(0 \%)$ & $3(30 \%)$ & $2(33.3 \%)$ & $>\mathbf{0 . 0 5}$ \\
+ve central + -ve lat & $4(100 \%)$ & $6(60 \%)$ & $3(50 \%)$ & \\
-ve central + +ve lat & $0(0 \%)$ & $1(10 \%)$ & $1(16.7 \%)$ & \\
\hline \multicolumn{1}{|c|}{} & $>\mathbf{0 . 0 5}^{*}$ & $>\mathbf{0 . 0 5}^{*}$ & $>\mathbf{0 . 0 5}$ & \\
\hline
\end{tabular}

In the group of single nodule (17/30, $56.7 \%)$; nine $(52.9 \%)$ had positive LNs and $8(47.1 \%)$ had negative LNs without significance between both groups $(\mathrm{P}=$ $0.231)$; in addition unilateral multifocal group (8/30, 26.7\%); 6 of them $(75 \%)$ had positive LNs and two (25\%) has negative LNs with significance correlation between unilateral multifocal cases and positive LNs $(\mathrm{P}=0.01)$. finally, bilateral multifocal cases $(5 / 30,16.7 \%)$; three of them (60\%) had positive LNs and two (40\%) had negative LNs without significance between both groups of LNs (0.321) (Table 8).

Table (8): Relation between nature of the swelling and +ve L.Ns.

\begin{tabular}{|l|c|c|c|c|c|}
\hline \multirow{2}{*}{ Nature of detection } & \multicolumn{2}{|c|}{ +ve L.Ns } & \multicolumn{2}{c|}{-ve L.Ns } & \multirow{2}{*}{ P } \\
\cline { 2 - 5 } & No. & $\%$ & No. & $\%$ & \\
\hline Single nodule & 9 & $52.9 \%$ & 8 & $47.1 \%$ & \multirow{2}{*}{ U.05 } \\
Unilateral multifocal & 6 & $75 \%$ & 2 & $25 \%$ & \\
Bilateral multifocal & 3 & $60 \%$ & 2 & $40 \%$ & \\
\hline
\end{tabular}

Positive LNs were present in all cases of capsular invasion $(7 / 7,100 \%)$ with highly significance correlation between capsular invasion and positive LNs $(\mathrm{P}=$ $0.000)$ while absence of capsular invasion associated with positive LNs in 11 cases
$(11 / 27,47.8 \%)$ and negative LNs were present in 12 cases $(12 / 27,52.2 \%)$ in this group without significance between the presence or absence of LNs in absence of capsular invasion $(\mathrm{P}=0.365)$ (Table 9).

Table (9): Relation between capsular invasion and +ve L.Ns.

\begin{tabular}{|c|c|c|c|c|c|}
\hline \multirow{2}{*}{ Capsular invasion } & \multicolumn{2}{|c|}{ +ve L.Ns } & \multicolumn{2}{|c|}{-ve L.Ns } & \multirow{2}{*}{$\mathbf{P}$} \\
\hline & No. & $\%$ & No. & $\%$ & \\
\hline Present & 7 & $100 \%$ & $\mathbf{0}$ & $0.0 \%$ & $<0.02$ \\
\hline Absent & 11 & $\mathbf{4 7 . 8 \%}$ & 12 & $52.2 \%$ & $>0.05$ \\
\hline $\mathbf{P}$ & \multicolumn{2}{|c|}{$>0.05$} & \multicolumn{2}{|c|}{$<0.001$} & \\
\hline
\end{tabular}


Twenty-six of our cases were papillary carcinoma $(26 / 30,86.7 \%)$ while 4 cases $(4 / 30,13.3 \%)$ with a significance of predominance of papillary carcinoma in our group of cases $(\mathrm{P}<0.001)$ (Table 10).

Table (10): Relation between different types of differentiated thyroid cancer.

\begin{tabular}{|c|c|c|}
\hline Histopathologic variants & No. & $\%$ \\
\hline Papillary thyroid carcinoma: & 26 & $86.7 \% \%$ \\
\hline Well differentiated papillary carcinoma & 20 & $76.9 \%$ \\
\hline Papillary Microcarcinoma & 3 & $11.5 \%$ \\
\hline Follicular variant of papillary carcinoma & 3 & $11.5 \%$ \\
\hline Follicular carcinoma & 4 & $13.3 \%$ \\
\hline $\mathbf{P}$ & \multicolumn{2}{|c|}{$<0.001$} \\
\hline
\end{tabular}

\section{DISCUSSION}

Enlargement of thyroid gland is a common occurrence in most parts of the world especially in the iodine deficient goiter belt areas, where the prevalence may be as high as $40 \%$. The development of goiter is a concern to both the patient and the clinician because of the fear that the swelling may be malignant. Most goiters are benign and even in solitary nodules selected for surgery or clinical grounds malignancy is found in only around 10\% (Hirachand et al., 2013).

This was a prospective study conducted on 30 cases of thyroid swelling diagnosed as thyroid cancer admitted to the Surgical Oncology Department of AlAzhar University Hospital and Damanhour Oncology Center.

Our study revealed that the age of patients was in the fifth decade of life.

Santosh and his Colleagues (2014) found in their study that the patients were in the second and third decades of life which disagree with our results.

This study revealed that females more commonly affected than males with a male to female ratio of 1:2.7.
Santosh and his Colleagues (2014) revealed in their study that females were more commonly affected than males with a male to female ratio of 1:9 which coincides with our study results.

Borsaikia and Patar (2016) revealed in their study that females were more commonly affected $(83.5 \%)$ by thyroid swelling than males $(16.5 \%)$ which was in agreement with our results.

Halbhavi and his Coworkers (2018) found in their study that females were more commonly affected than males with a male to female ratio of 1:9 which was in agreement with our results.

The main presenting symptom in our cases was neck swelling mainly nodular with little cases of smooth swelling.

Santosh and his Colleagues (2014) revealed in their study that the main presenting feature was the presence of a swelling in front of the neck in $35 \%$ of patients which was in agreement with our study results.

Borsaikia and Patar (2016) revealed in their study that all cases of their study $(100 \%)$ presented by swelling in the thyroid region of the neck which coincides with our results. 
Halbhavi and is Coworkers (2018) found in their study that the main presenting symptom was swelling in the thyroid region of the neck $(100 \%)$ which coincides with our results.

Remonti and his Coworkers (2015) revealed in their study that ultrasonographic examination of the thyroid swelling showed hypoechogenicity, irregular margins, microcalcifications, and absent halo suggesting malignant nature which was in agree with our results.

Brito and his Coworkers (2014) revealed in their study that by ultrasonography of the neck the swellings that showed cystic nature or spongiform appearance signifying benign nature which disagreed with our results.

That is because, pure cystic lesions are always thought to be benign; on the contrary, polyconcamerated cysts and complex nodules may harbor a risk of malignancy. Also, a spongiform nodule may relay the overall impression of iso- to hyperechogenicity, but it must be distinguished from iso- or hyperechoic complex nodules with isolated discrete cystic areas, because the first are benign and the latter may be malignant.

Kwak and his Colleagues (2011) document in their study the high specific features for thyroid cancer are microcalcifications, irregular margins which agreed with our results.

The swelling discovered either by clinical examination or accidentally during examination of the neck for other diseases.

$\mathrm{Li}$ and his Colleagues (2013) and Davies with his coworkers (2014) found in their studies that the thyroid swelling were discovered either clinically on selfpalpation by the patient, or during a physical examination by the clinician or incidentally during a radiologic procedure such as ultrasonography (US) imaging, computed tomography (CT) which was in agreement with our study.

The histopathologic examination of our cases revealed that the most common carcinoma was papillary carcinoma than follicular carcinoma.

Tamhane and Gharib (2016) revealed in their study that the most common malignant carcinoma was the papillary carcinoma (97-99\%) and follicular carcinoma constitute about little percentage which agreed with our results.

Santosh and his Colleagues (2014) revealed in their study that only $10 \%$ of cases were malignant in nature while the remaining were benign which contradicts our results that found malignant swelling constitute nearly half the cases.

Borsaikia and Patar (2016) revealed in their study that follicular carcinoma (4.24\%) more commonly occurred than papillary carcinoma $(1.41 \%)$ which contradicts our results.

Hirachand and his Colleagues (2013) found in their study that the most common malignant neoplasms were papillary carcinoma which coincides with our results.

Our results revealed increase in the serum level of TSH in malignant cases than in benign cases.

Tamhane and Gharib (2016) reported in their study that Haymart with Coworkers (2008) concluded in their 
studies that increased serum TSH or TSH even in the upper limit of normal is associated with increased risk and an advanced stage of malignancy which disagree with our results.

Gharib and his Coworkers (2016) documented in their study that Gerschpacher and coworkers, (2010) concluded in his study that low levels of thyrotropin (TSH) are associated with a decreased probability of malignancy, whereas increased levels of serum TSH, even when the levels are still within reference limits, are statistically associated with an increased risk of cancer in thyroid nodular disease and this coincides with our results.

Randolph and his Colleagues (2012) found in their study that the impact of lymph node compromise on the prognosis is controversial and according to prevailing opinions, lymph node metastases that are macroscopic, present in large numbers or characterized by extracapsular extension increase the risk of relapse and mortality in patients older than 45 years old and this run in line with our results.

I131 was used as an apllative therapy for some of our cases Rosario and his Colleagues (2013) use I131 as a part of applative therapy for malignant cases of their study which was in agreement with our study.

\section{CONCLUSION}

Based on the results obtained by this sudy, we can conclude that Central neck dissection is still beneficial especially in high risk group of cases where there was capsular invasion.

\section{REFERENCES}

1. Barczyński M, Konturek A, Stopa $M$ and Nowak W. (2013): Prophylactic central neck dissection for papillary thyroid cancer. British Journal of Surgery, 100(3):410-418.

2. Borsaikia K and Patar M (2016): Clinicopathological Study of Thyroid Swellings with Some Emphasis on Geographical and Community Distribution:A Hospital Based Analysis. Bengal J Otorhinolaryngol Head Neck Surgery, 24(2):73-9.

3. Brito JP1, Gionfriddo MR, Al Nofal A, Boehmer KR, Leppin AL, Reading C, Callstrom M, Elraiyah TA, Prokop LJ, Stan MN, Murad MH, Morris JC, Montori VM. (2014): The accuracy of thyroid nodule ultrasound to predict thyroid cancer: systematic review and meta-analysis. J Clin Endocrinol Metab., 99(4): 1253-63.

4. Davies L and Welch HG (2014): Current thyroid cancer trends in the United States. JAMA Otolaryngol Head Neck Surg, 140(4): 317-22.

5. Friedman $M$, Kelley $K$ and Maley $A$. (2011): Central neck dissec-tion. Operative Techniques in Otolaryngology -Head and Neck Surgery, 22:169-72.

6. Gharib H, Papini E, Garber JR, Duick DS, Harrell RM, Hegedüs L, Paschke R, Valcavi R, Vitti P, AACE/ACE/AME Task Force on Thyroid Nodule (2016): Medical guidelines for clinical practice for the diagnosis and management of thyroid nodules - 2016 Update appendex. Endocrin Pract., 22(Suppl 1): 1-60.

7. Giordano D, Valcavi R, Thompson GB, Pedroni C, Renna L, Gradoni $P$ and Barbieri V. (2012): Complications of central neck dissection in patients with papillary thyroid carcinoma: results of a study on 1087 patients and review of the literature. Thyroid, 22(9):911-917.

8. Giugliano G, Proh M, Gibelli B, Grosso E, Tagliabue M, De Fiori E, Maffini F, Chiesa F and Ansarin F (2014): Central neck dissection in differentiated thyroid cancer: technical notes. ACTA otorhinolaryngologica ita lica, 34:9-14. 
9. Goffredo P, Roman SA and Sosa JA (2013): Hurthle cell carcino-ma: a population-level analysis of 3311 patients. Cancer, 119:504-11.

10. Halbhavi SN, Ganjigatti M, Kuntoji SB and Karikazi MA (2018): Clinicopathological study of thyroid swellings in HSK hospital in Karnataka, India. Int Surg J, 5(2): 420-425.

11. Haugen BR, Alexander EK, Bible KC, Doherty GM, Mandel SJ, Nikiforov YE, Pacini F, Randolph GW, Sawka AM, Schlumberger M1, Schuff KG, Sherman SI, Sosa JA, Steward DL, Tuttle RM and Wartofsky L (2016): American Thyroid Association management guide-lines for adult patients with thyroid nodules and differentiated thyroid cancer. Thyroid, 26:1133.

12. Haymart MR, Repplinger DJ, Leverson GE, Elson DF, Sippel RS, Jaume JC and Chen H (2008): Higher serum thyroid stimulating hormone level in thyroid nodule patients is associated with greater risks of differentiated thyroid cancer and advanced tumor stage. J Clin Endocrinol Metab, 93(3):809-14.

13. Hennessy $M$ and Goldenberg $D$ (2016): The Role of Prophylactic Central Neck Dissection in the Treatment of Differentiated Thyroid Cancer. Rambam Maimonides Med J., 7 (1):e0007.

14. Hirachand S, Maharjan $M$, Lakhey $M$, Thapa $R$ and Kafle $S$ (2013): Accuracy of fine needle aspiration cytology in diagnosis of thyroid swelling. J Pathol Nepal, 3: 433436.

15. Kwak JY, Han KH, Yoon JH, Moon HJ, Son EJ, Park SH, Jung HK, Choi JS, Kim BM and Kim EK (2011): Thyroid imaging reporting and data system for US features of nodules: a step in establishing better stratification of cancer risk. Radiology, 260: 892-899.

16. Li N, Du XL, Reitzel LR, Xu L, Sturgis EM (2013): Impact of enhanced detection on the increase in thyroid cancer incidence in the United States: review of incidence trends by socioeconomic status within the surveillance, epidemiology, and end results registry, 19802008. Thyroid, 23(1): 103-1

17. Pellegriti G, Frasca F, Regalbuto C, Squatrito S, Vigneri R (2013): Worldwide increasing incidence of thyroid cancer: update on epidemiology and risk factors. J Cancer Epidemiol, 965212.

18. Pietro G C, Fabio $M$, Giuseppe $P$, Francesco B, Germana B, Stefano Mariotti, and Angelo N (2013): Differentiated Thyroid Cancer: Indications and Extent of Central Neck Dissection. International Journal of Surgical Oncology, 625193.

19. Prescott JD and Udelsman $R$ (2012): Central neck dissection. In: Oertli D, Udelsman R, editors. Surgery of the thyroid and parathyroid glands. 2nd ED. Berline Heidelberg. Springer-Verlag, Pp 215-221.

20. Randolph GW, Duh QY, Heller KS, LiVolsi VA, Mandel SJ, Steward DL, Tufano RP and Tuttle RM (2012): The prognostic significance of nodal metastases from papillary thyroid carcinoma can be stratified based on the size and number of metastatic lymph nodes, as well as the presence of extranodal extension. Thyroid, 22: 1144-52.

21. Ray B1, Pugazhandhi B, D'Souza AS, Saran S, Fasil M and Srinivasa RS (2012): Analysis of the arterial anatomical variations of thyroid gland: anatomic guide for surgical neck dissection. Bratislavskelekarske listy, 113(11): 669-72.

22. Remonti LR, Kramer CK, Leitao CB, Pinto LC and Gross JL (2015): Thyroid ultrasound features and risk of carcinoma: a systematic review and meta-analysis of observational studies. Thyroid, 25(5): 538-50.

23. Santosh UP, Kumar KBS, Trupthi MC and Boobalan S (2014): A comprehensive approach to thyroid swelling: Clinical, sonographic, cytological and histopathological correlation. Otorhinolaryngol Clin Int J., 2: 28-31.

24. Tamhane $S$ and Gharib H, (2016): Thyroid nodule update on diagnosis and Management. Clin Diabet Endocrinol., 2: 17-26. 
دور تشربح الغدد اللبمفاوبة المركزبة بالر قبة فى السرطان

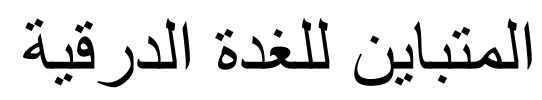

محمد إبراهيم العنانى، محمد ممدوح أحمد، أحمد عادل عبد الفتاح عبد الرحيم قسمي الجراحة العامة وجراحة الأورام ، كلية الطب، جامعة الأزهر (القاهرة)

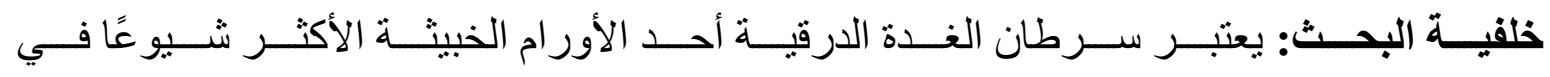

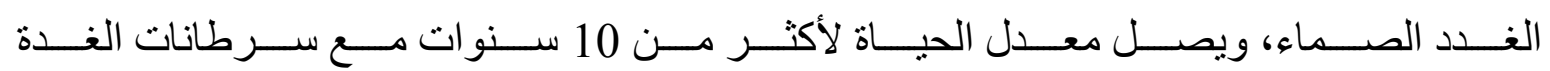

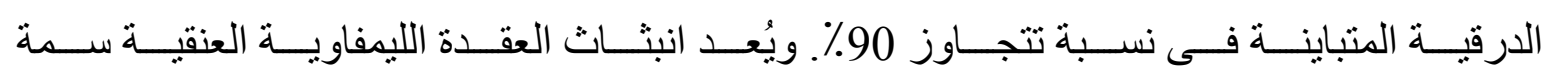

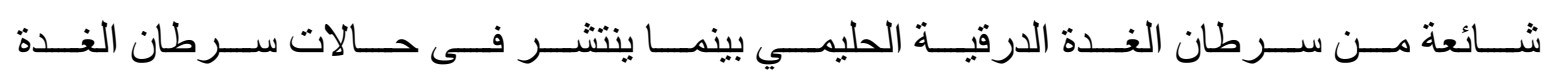
الدرقية المسامي غالباً فى الدم.

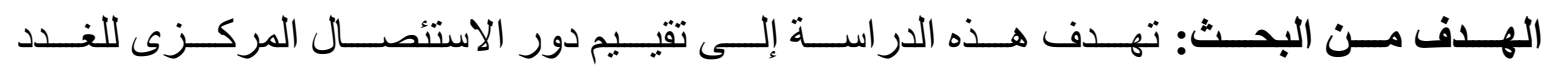

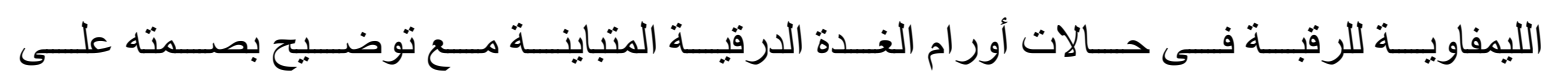
معدلات الإعتلال و النتائج العامة لهذا العلاج.

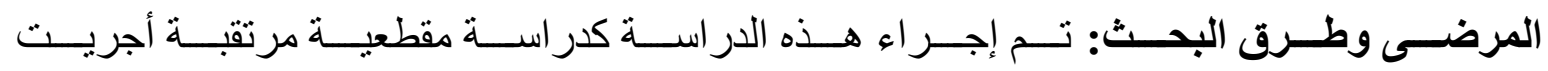

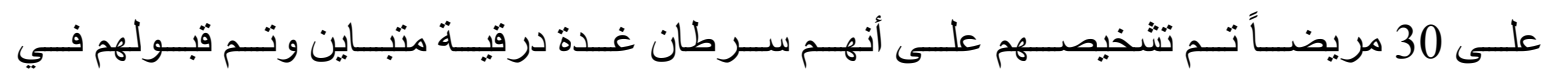

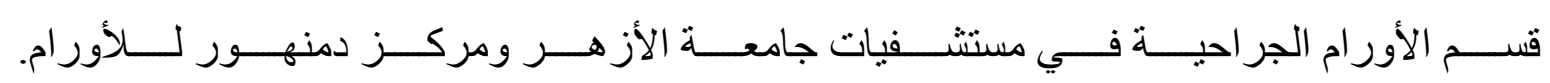

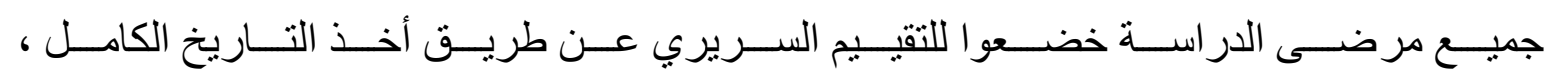

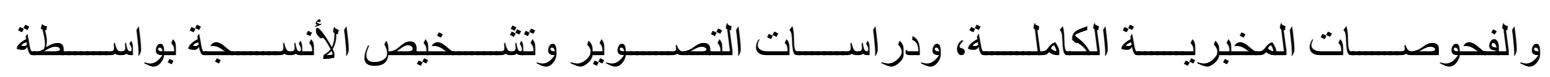
أخذ عينة بالإبر الدقيقة.

نتــائج البحــث: أظهــرت الدراســة وجــود علاقــة بــين الغــد الليمفاويــة الإيجابيــة والــورم

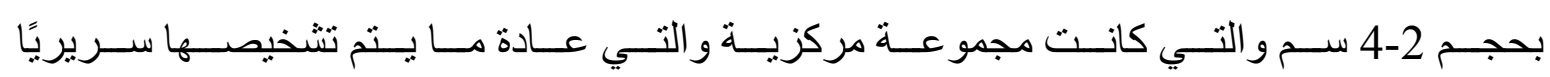

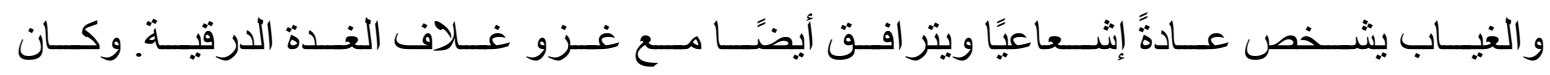

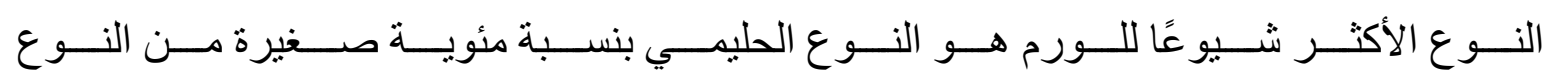

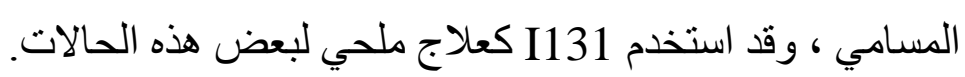

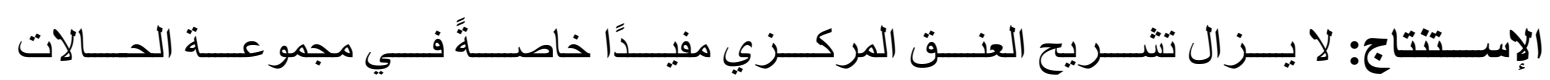
الثديدة الخطورة حيث كان هناك غزو غلاف الغدة الدرقية. 